\title{
Moderately accelerated intensity-modulated radiation therapy using simultaneous integrated boost: practical reasons or evidence-based choice? A critical appraisal of literature
}

\begin{tabular}{|r|l|}
\hline Journal: & Head \& Neck \\
\hline Manuscript ID & HED-20-0230 \\
\hline Wiley - Manuscript type: & Clinical Review \\
\hline Date Submitted by the & 24-Feb-2020 \\
\hline Complete List of Authors: & $\begin{array}{l}\text { De Felice, Francesca; Sapienza University of Rome, Department of } \\
\text { Radiotherapy, Policlinico Umberto I, "Sapienza" University of Rome, } \\
\text { Italy. } \\
\text { Bonomo, Pierluigi; Azienda Ospedaliero Universitaria Careggi, Radiation } \\
\text { Oncology } \\
\text { Sanguineti, Giuseppe; Regina Elena Institute, Radiotherapy Department, } \\
\text { Istituto Tumori Regina Elena, Rome, Italy } \\
\text { Orlandi, Ester; Fondazione IRCCS Istituto Nazionale dei Tumori, } \\
\text { Radiotherapy }\end{array}$ \\
\hline Key Words: & $\begin{array}{l}\text { Head and neck cancer, Squamous cell carcinoma, Radiotherapy, } \\
\text { Intensity-modulated radiotherapy, Simultaneous integrated boost }\end{array}$ \\
\hline
\end{tabular}

\section{SCHOLARONE $^{\text {m }}$ Manuscripts}


Moderately accelerated intensity-modulated radiation therapy using simultaneous integrated boost: practical reasons or evidence-based choice? A critical appraisal of literature

Francesca De Felice ${ }^{1}$ MD, Pierluigi Bonomo² MD, Giuseppe Sanguineti ${ }^{3}$ MD, and Ester Orlandi ${ }^{4} \mathrm{MD}$

1 Department of Radiotherapy, Policlinico Umberto I, "Sapienza" University of Rome, Italy.

2 Radiation Oncology, Azienda Ospedaliero - Universitaria Careggi, University of Florence, Italy

3 Radiotherapy Department, Istituto Tumori Regina Elena, Rome, Italy

4 Radiotherapy 2 Unit, Fondazione IRCCS Istituto Nazionale dei Tumori, Milan, Italy

Corresponding author:

Pierluigi Bonomo, MD.

Radiation Oncology, Azienda Ospedaliero - Universitaria Careggi, University of Florence, largo Brambilla 3, 50134 Florence, Italy

Tel: +39 055-7947261

Fax +39 055-7947363

Email: bonomopierlu@gmail.com

Orcid code: 0000-0001-8999-5208 
Funding information: no funding was received for this work

Conflict of interest statement: none declared.

Running title: SIB-IMRT: practical reasons or evidence-based choice?

\section{Keywords}

Head and Neck Cancer; Squamous cell carcinoma; Radiotherapy; Intensity modulated radiotherapy; Simultaneous integrated boost. 


\title{
Moderately accelerated intensity-modulated radiation therapy using simultaneous integrated boost: practical reasons or evidence-based choice? A critical appraisal of literature
}

\begin{abstract}
Concurrent chemo-radiotherapy is the non-surgical mainstay of treatment for locally advanced head and neck squamous cell carcinoma (HNSCC). The following aspects have emerged as fundamental components of the combined approach: first, intensity modulated radiotherapy (IMRT) is the minimum standard technical requirement, with level 1 evidence in support of its reduction of late treatment-induced morbidity in comparison with 3D conformal radiotherapy. Second, cisplatin - based chemotherapy is the preferred systemic agent to be associated with radiation, with $100 \mathrm{mg} / \mathrm{m}^{2}$ every 3 weeks deemed as the reference schedule. Because of significant progress in irradiation techniques achieved in last 15 years, the optimal fractionation schedule in modern radiation era remains controversial, especially for locally advanced disease. The purpose of this work was to perform a critical review on the value of moderately accelerated IMRT using simultaneousintegrated boost (SIB) in HNSCC, aiming to provide insights on current clinical practice and directions for future research.
\end{abstract}




\section{Moderately accelerated intensity-modulated radiation therapy using simultaneous integrated boost: practical reasons or evidence-based choice? A critical appraisal of literature}

\section{Introduction}

Head and neck squamous cell carcinoma (HNSCC) is a remarkably heterogeneous malignancy and improving survival outcome continues to be a major challenge for clinicians, particularly for patients with locally advanced disease [1]. Today, especially in the USA and Western Europe, a growing number of HNSCC cases is human papilloma virus (HPV)related, being HPV positivity recognized as a strong prognostic factor [2]. Depending on clinical circumstances, cisplatin-based chemo-radiotherapy (CRT) represents the standard of care, both in primary and adjuvant setting [1]. At present, intensity-modulated radiotherapy (IMRT) is the preferred technique for HNSCC management [1]. Its main advantage over 3-dimensional (3D) conformal radiation therapy (RT) is to confine high dose intensities to target volumes while dropping doses to surrounding organs at risk and thus reducing morbidity. Traditionally, dose per fraction ranges from 1.8 to 2 Gray (Gy) up to a total dose of 50-70 Gy using a sequential boost (SEQ) to the primary or the tumor bed [1]. Simultaneous integrated boost (SIB) has been developed to improve planning efficiency and assure dose escalation to macroscopic disease [3]. SIB-IMRT is a favorable solution mainly because it allows i) different therapeutic dose levels to target volumes with a higher biologically equivalent dose (BED) to the gross tumor with single dose fraction slightly higher than 2 Gy, ii) a single plan with intrinsic tight dose distribution, iii) a shorter overall treatment time (OTT), iv) a concurrent CRT approach, v) a superior dose painting when advanced techniques are available, such as intensity-modulated arc therapy and volumetric modulated arc therapy. However, over the years, several fractionation modifications with or without 
concomitant chemotherapy (CHT) have been tested to improve therapeutic ratio and potentially enhance tumor control [3]. Briefly, three types of altered fractionation have been proposed: hyperfractionated (higher total dose with $1.2 \mathrm{~Gy} /$ fraction delivered twice daily and same OTT), moderately accelerated (same total dose and shorter OTT) and very accelerated (lower total dose and shorter OTT) [4]. The updated meta-analysis of radiotherapy in squamous cell carcinomas of head and neck $(\mathrm{MARCH})$ defined the crucial role of hyperfractionated RT over other altered fractionation regimens, due to its absolute benefit in overall survival (hazard ratio, $\mathrm{HR}=0.83,95 \%$ confidence interval $\mathrm{Cl} 0.74-0.92$ ) with an absolute difference at 5 years of $8.1 \%(95 \% \mathrm{Cl} 3.4-12.8)$ [5]. However, there is no consensus on what fractionation should be considered standard of care in concurrent CRT. This article provides an insight on current fractionation schedules to potentially suggest a more tailored treatment approach in patients with locally advanced HNSCC. We focused on the available evidence supporting altered fractionation (AF) and SIB-IMRT.

\section{Discussion}

Literature search strategy

All the available literature, including abstracts and full text manuscripts, regarding altered fractionation and concomitant CRT strategies in non-metastatic locally advanced HNSCC was reviewed. PubMed search was performed between January 2009 and November 2019 using the following combinations of research criteria: "cancer", "carcinoma", "head and neck", “oral cavity”, “oropharyngeal”, “oropharynx”, "hypopharynx”, “larynx”, "human papilloma virus”, “HPV”, “radiotherapy”, “IMRT”, "altered fractionation”, "hyperfractionation”, "accelerated fractionation", "SIB" and "toxicity". Only publications in English were retained. 
We excluded studies including mostly postoperative cases or nasopharyngeal cancer patients only or those without survival outcomes and/or toxicities analysis and/or details on dose prescription. Reference lists of previously published consensus guidelines, reviews and meta-analyses were explored. Abstract from international meetings (European Society of Medical Oncology, European SocieTy for Radiotherapy \& Oncology, American Society for Radiation Oncology and American Society of Clinical Oncology) were included only if with appropriate and sufficiently powered statistical data. For the sake of our analysis, we referred to CRT as the preferred non-operative, curatively-intended strategy. Thus, we did not include induction chemotherapy trials since in the frame of non-nasopharyngeal HNSCC alone its role (followed by RT alone) is supported by level 1 evidence for larynx preservation purpose only. To evaluate the impact of RT schedule in the current IMRT era, we decided to focus primarily on phase III studies in order to support our analysis with the highest level of evidence available. In addition, the largest retrospective series including at least 80 patients using accelerated SIB-IMRT with or without a comparison with conventional sequential IMRT approaches were eligible. Based on these criteria, a total of 31 manuscripts were considered. Details of the main studies reviewed are reported in Table 1 (SIB-IMRT retrospective series) and Table 2 (IMRT randomized trials).

\section{Altered fractionation: the background}

A remarkable lesson from published studies over the past 25 years testing altered fractionated regimens for the primary treatment of locally advanced HNSCC has been that both AF and hyperfractionation (HF) have shown therapeutic gains compared to conventional fractionation (CF) with 2 Gy per day to a total of 70 Gy over 7 weeks. In particular, AF reducing OTT by 1 week, either by giving six fractions of 2 Gy per week without total dose changes or by using a concomitant boost (CB) strategy with a $3 \%$ increase of the 
total dose, allowed a significantly better loco-regional control (LRC) compared to CF (approximately 15\% absolute improvement). As expected, acute toxicity increased as well, but the risk of clinically significant late effects did not [6]. Also HF trials using 1.1-1.2 Gy per fraction with a total dose escalation of $7-17 \%$ over $6-7$ weeks showed a significantly better LRC, with significantly higher acute oral mucositis rates and no detectable increase in late normal-tissue injury compared to CF [6]. The MARCH meta-analysis update, including 34 randomized trials representing 11969 patients with mostly (75\%) primary oropharynx or larynx lesions, showed that HF led to a significantly higher overall survival benefit $(8.1 \%$ at 5 years) over CF than AF without total dose changes, even if slightly different patient populations had been considered in each fractionation group [5]. The clinical superiority of HF has been also emphasized in the Radiation Therapy Oncology Group (RTOG) 9003 study [7]. To date, the RTOG 9003 is the largest randomized trial on pure RT fractionation. Although the cumulative incidences of loco-regional failure were very similar between HF and AF-CB arms, at 5-years HF but not AF improved LRC and OS without increasing long term toxicity over CF [7]. Despite the achievement of identical LRC rates, the reason for HF benefit over AF remains unknown. Within the RTOG, HF did not become the standard or "control" RT fractionation to be used in controlled investigations. Logistic and financial reasons along with early trial results favored AF-CB over HF [7]. Indeed, preliminary clinical data showed the superiority of both AF-CB and HF over CF in terms of LRC without difference in persistent severe late toxicity among fractionation regimens [7]. Thus, several schedules have been investigated in the subsequent RTOG trials to test the best approach with or without CHT. In RTOG 0129 trial, patients with locally advanced HNSCC were randomized to either CF plus concomitant cisplatin (three-weekly $100 \mathrm{mg} / \mathrm{m}^{2}$ for 3 cycles) or AF-CB with concomitant cisplatin (100 mg/m² for 2 cycles) [8]. In the AF group, treatment acceleration was achieved by giving the boost dose as second daily dose in the last 12 treatment days. Therefore, the primary tumor and involved neck nodes were planned to 
receive 72 Gy in 42 fractions over 6 weeks reducing OTT by 1 week over CF. However, IMRT was not allowed and radiation technique consisted of 2D/3D conformal RT [8]. Interestingly, there were no significant differences between AF plus two cycles of cisplatin and CF plus three cycles of cisplatin [8]. Based on these results, the RTOG 0522 trial was designed accordingly [9]. IMRT was used and treatment acceleration was achieved by delivering 6 fractions per week for 5 weeks concomitantly to two cycles of cisplatin at usual dosage [9]. The OTT reduction strategy was similar to that investigated in the Danish Head and Neck Cancer Group (DAHANCA) 6 and 7 trials: one fraction daily, from Monday to Friday, and the sixth fraction given on Saturday or Sunday, or as an extra fraction on a weekday, with at least six-hour interval between consecutive fractions. In addition to different tumor sites - glottic larynx in DAHANCA 6 and supraglottic larynx, pharynx and oral cavity tumors in DAHANCA 7 -, the main difference between the two DAHANCA trials was that the DAHANCA 6 dealt only with the fractionation effect, whereas the DAHANCA 7 included treatment with the hypoxic radiosensitiser nimorazole [10]. Compared to CF, the six-fractions-weekly regimen assured a significant control benefit on primary tumor (76\% versus $64 \%$ ) but did not improve regional control [10]. The general benefit of this AF strategy has been confirmed in the International Atomic Energy Agency (IAEA) ACC trial, concluding that it could be effectively applied in developing countries, where few therapeutic resources are available, potentially being a new international standard of treatment [11]. Over the years, accelerated regimen of six fractions of RT per week has become a standard option in the United States as well as a common fraction regimen in the RTOG investigations [1]. For instance, in the recently published NRG Oncology RTOG 1016 trial, patients with locally advanced HPV-positive oropharyngeal carcinoma received accelerated IMRT delivered at 70 Gy in 35 fractions over 6 weeks at six fractions per week (with two fractions given on one day, at least 6 hours apart) and were randomly assigned to receive either concomitant cetuximab or cisplatin [12]. 
It should be acknowledged that in the accelerated IMRT era reducing OTT by 1 week according to the DAHANCA andRTOG trials is more convenient and less expensive than AF-CB or HF RT. However, at present, based on the MARCH-HPV project results, the RT fractionation regimen cannot be solely based on HPV status because its expression had no predictive impact on response to AF [13].

Simultaneous integrated boost: what's the evidence?

SIB-IMRT is a dose painting strategy that assures dosimetric and safety advantages over SEQ-IMRT plans [14]. It allows to implement a dose-escalation approach using fraction size (FS) higher (> 2.0 Gy per fraction - hypofractionation) than the conventional 2 Gy per fraction. Assuring OTT reduction and same total dose over CF, SIB-IMRT represents an option to achieve acceleration but without changing the number of weekly fractions. Its main limit is the intensity of normal tissue toxicity, both in acute and late phases (as consequence of acceleration itself). The increase in single fraction dose reduces the therapeutic gain, since the FS is the main factor determining late effect and influencing early responder tissues $[15,16]$. It is axiomatic that with dose escalation there should be limitation to the irradiated volume. This is certainly true for 2D/3D conformal RT. Actually, due to the strict "conformal avoidance" of critical structures achievable with SIB-IMRT, the delivery of high FS to high risk volume in a shortened OTT should be hazardous only for normal tissues embedded in this volume [17]. Mohan suggested an unacceptable toxicity in case of fraction number lower than 30 and total dose escalation over 70 Gy [14]. In these conditions it could be prohibitive to add concomitant $\mathrm{CHT}$. In the last few years, a variety of accelerated hypofractionated SIB-IMRT regimens have been employed worldwide, without the possibility to define a standard. Main retrospective series are listed in Table 1. On the whole, a marked heterogeneity in terms of number of patients, primary tumor site, disease stage, RT setting, 
concomitant systemic approach and study design makes any comparison difficult. Similarly, a plethora of IMRT fractionation regimes (12 fractionation schedules over 14 cancer centers around the world) in HNSCC has been described by Ho et al [18]. The vast majority of centers employed an accelerated fractionation. Among these schedules, the modestly hypofractionated regimen ( $\leq 2.2$ Gy per fraction, with an OTT ranging from 6 to 6.5 weeks) and the dose escalated hypofractionated schedule (> 2.3 Gy per fraction, with higher total dose and OTT of 5 to 6.5 weeks) were most commonly used (in 2 and 4 centers, respectively) on top of concomitant platinum-based $\mathrm{CHT}$ [18]. In several large retrospective series, dose per fraction to high risk target volume was increased up to 2.2 Gy per fraction for a total dose of 66-69.96 Gy in 30-33 fractions [19-24]. This altered fractionation schedule was usually associated with concomitant $\mathrm{CHT}$. Median follow-up ranged from 17 and 37 months. Overall, local control and survival outcome were excellent, with percentage (at a minimum 2-year time point) in the range of $80-90 \%$ and $80 \%$, respectively. Even though in the reports by Studer [22] and Daly [24] the type and frequency of acute and late effects referred to both definitive and postoperative cases, severe acute mucositis and dysphagia occurred in $15-50 \%$ of patients in the remaining series whereas late severe toxicities were reported with a very low frequency. To put the results of largest retrospective SIB series into perspectives, fractionation regimens and outcome results from phase III randomized trials are reported in table 2 [9, 12, 25-29]. Moderately accelerated RT in 6 weeks with concomitant cisplatin- based $\mathrm{CHT}$ was the reference arm in the majority of studies, regardless the primary endpoint of trial. Two trials were designed with a different "standard treatment" regarding concomitant CHT. In particular GORTEC 2007-01 trial [27] was designed to investigate the effect of adding concurrent cetuximab to a carboplatin-5 fluorouracil backbone and RT (given as conventionally fractionated IMRT with sequential approach) compared with bio-radiotherapy in locally advanced HNSCC. The PARSPORT trial was designed to assess parotid-sparing IMRT compared with conventional RT [28]. In 
the IMRT group, a SIB-IMRT was prescribed. Namely, primary tumor and involved lymph nodes were treated with 65 Gy in 30 fractions (2.16 Gy per fraction, 5 days per week) and nodal levels received 54 Gy in 30 fractions (1.8 Gy per fraction, 5 days per week). No concurrent $\mathrm{CHT}$ was administered, but patients who had received induction $\mathrm{CHT}$ were eligible. Both radiation-induced xerostomia and global quality of life scores were significantly better in patients treated with SIB-IMRT compared with conventional RT, whereas there were no differences in terms of LRC and OS rates between groups. Recently, two phase 3 trials, the De-ESCALaTE [29] and RTOG 1016 [12] investigated the role of a deintensification approach in HPV-positive oropharyngeal cancer testing cetuximab in place of cisplatin concurrently with RT. Interestingly, RT was delivered with CF in the De-ESCALaTE study and with acceleration in six weeks in the RTO G1016 trial. Both studies failed in demonstrating that bio-radiotherapy was associated with non-inferior survival and comparable toxicity profile compared with cisplatin-based CRT.

Overall, the safety and tolerability of SIB as a dose-painting strategy was tested in a small number of prospective phase 1/2 trials, with or without concomitant or neoadjuvant $\mathrm{CHT}$ [30, 31]. Lauve et al [30] demonstrated that a total dose of $70.8 \mathrm{~Gy}$ in 30 fractions of $2.36 \mathrm{~Gy}$ can be safely delivered as the sole treatment in HNSCC. This SIB-IMRT regimen defined the maximum tolerated dose. Higher daily dose per fraction (2.46 Gy) resulted in uncontrolled severe toxicity onset resulting in prolonged RT break [30]. On the other hand, Leclerc at al described the feasibility of dose escalation up to 75 Gy in 30 fractions of 2.5 Gy using SIBIMRT without concomitant CHT in early and moderately advanced (T2 N0-1 and T3 N0) HNSCC cases [31]. Data from SIB-IMRT with concomitant CHT studies with three different doses per fraction (2.25 Gy to a total dose of $63 \mathrm{~Gy}$ in 28 fractions; 2.4 Gy to a total dose of 67.2 Gy in 28 fractions; 2.17 Gy to a total dose of 65 Gy in 30 fractions) have been described in literature [32]. These studies demonstrated that incidence, peak prevalence and recovery from severe dysphagia and oral mucositis were significantly higher in patients receiving 2.4 
Gy per fraction [32]. Final long term results revealed high 5-year LRC, PFS, and organ preservation rates, with acceptable late toxicity $(6.4 \%$ of cases developed late severe dysphagia) [33]. Another strategy to improve loco-regional control minimizing late normal tissue toxicity was performed using SIB-IMRT with concurrent cetuximab [34]. Patients with stage II-III disease (T2-3 N0; T1-3 N1) were treated with 62.5 Gy in 25 daily fractions over 5 weeks. This treatment modality was effective on tumor control with an acceptable acute toxicity, low rate of late toxicity and marginal impact on quality of life [34]. It is pivotal to underline that in this trial, the extension of the high risk and low risk volumes are smaller than those usually defined in locally advanced disease including T4, N2 and N3 stages. Thus, a marked acceleration in 5 weeks without an increase in total dose was shown to be tolerable for this distinct category.

To summarize, the consistency of all these results confirms the safety and the feasibility of a hypofractionated accelerated SIB-IMRT concomitant to CHT or cetuximab with a total dose equal or slightly inferior to 70 Gy in 30 to 33 fractions in the majority of cases.

Based on these assumptions, a main question remains:

What accelerated fractionation should be considered standard of care in concomitant CRT approach?

Based on 87 randomized trials representing 17,346 patients, the meta-analysis of chemotherapy in head and neck cancer (MACH-NC) clearly established an absolute OS benefit of $4.5 \%$ at 5 years for chemotherapy and a more pronounced benefit of the concomitant CRT as compared to sequential approaches [35]. While the superiority of AF and SIB-IMRT over FC has been proven, the optimal accelerated fractionation to be used remains to be firmly established. A recent meta-analysis compared treatment outcomes of conventionally fractionated CRT versus AF alone [36]. In total, 5 randomized trials (1117 patients) were included in the final analysis [37-41]. Despite different patient and treatment 
characteristics, all these studies directly randomized patients to conventionally fractionated CRT or an accelerated regimen arm. One trial used a split-course AF schedule - 1.6 Gy per fraction, 2 fractions daily, 5 days/week for a dose of 64-67.2 Gy with planned 2 week treatment gap after 2.5 weeks - [37]; two trials used two different forms of acceleration, including very accelerated (1.8 Gy per fraction, 2 fractions daily, 5 days/week for a total dose of $64.8 \mathrm{~Gy}$ in 36 fractions in 3.5 weeks) and accelerated regimen s(2 Gy per fraction, 6 days/week for 66-70 Gy) [38, 39]; the others used a CB regimen boosting primary tumor and positive nodes at $1.2 \mathrm{~Gy} /$ fraction given $6-8$ hours apart during last 2 weeks of RT or 1.5 Gy/fraction given 6 hours apart during last 3 weeks [40,41]. Overall, the results provided moderate (for OS and disease-free survival) and low (for LRC) quality evidence mainly due to small sample size and severe indirectness of included studies [36]. In fact, three trials used carboplatin with 5-fluorouracil and one weekly cisplatin, respectively [37-40]. Only one trial used the standard three-weekly cisplatin-based CHT [41]. In addition, HF RT was not performed in any of them, despite its proven efficacy compared to conventional RT [4].

The combination of CHT and HF RT has been examined in a subsequent meta-analysis, including six trials and 1280 patients [42]. Results supported the role of concurrent CHT and HF RT. Compared to HF alone, concomitant treatment showed improvement in OS (HR 0.77, Cl 95\% 0.66-0.89), cancer-specific survival (HR 0.72, Cl 95\% 0.60-0.88), progressionfree survival (HR 0.74, Cl 95\% 0.63-0.87) and LRC (HR 0.64, Cl 95\% 0.55-0.75) without a significant increase in severe acute and late toxicities. However, it should be noticed that in individual studies, concomitant CHT schedules, as well as RT techniques, were not the standard of care in daily HNSCC practice. No firm conclusions can be drawn but probably it is possible to speculate that direct comparisons of HF versus CF, both with concomitant $\mathrm{CHT}$, might result in clinical benefit. At present, this assumption is supported by a mixed treatment comparison meta-analysis showing that CRT using moderate HF and platinumbased concurrent $\mathrm{CHT}$ leads to the highest probability of survival, compared with other 
treatment modalities [43]. Moreover, a notable finding is that acceleration might compensate the absence of a third cycle of concomitant $\mathrm{CHT}[9,38]$. According to the MACH-NC metaanalysis, concomitant platin-based CHT is associated to the maximum survival benefit [35]. But benefit of concomitant CHT appears to be dissimilar depending on its cumulative dose. At present the recommend dose is cisplatin $100 \mathrm{mg} / \mathrm{m}^{2}$, three times during $\mathrm{RT}$, up to a cumulative dose of $300 \mathrm{mg} / \mathrm{m}^{2}$ [1]. However, in routine practice, a substantial fraction of patients do not receive the third planned cycle due to severe toxicity, primarily mucositis. Establishing the minimal cumulative dose able to guarantee a beneficial antitumor effect while reducing toxicity could be an important clinical issue.

The relevant literature on survival results after RT alone and concurrent cisplatin-based CRT indicated a significant positive correlation between OS improvement and higher cumulative cisplatin dose, even though an effective benefit beyond the cumulative cisplatin dose of 200 $\mathrm{mg} / \mathrm{m}^{2}$ is confounded [44]. A pooled analysis of 404 HPV-positive and 255 HPV-negative HNSCC patients demonstrated a survival benefit of cumulative dose $>200 \mathrm{mg} / \mathrm{m}^{2}$ in HPVnegative cases, but not in HPV-positive cohort, although T4 or N3 disease may benefit from a higher cisplatin dose [45].

\section{Conclusion}

Robust literature data have consistently demonstrated that treatment intensification, either by concomitant $\mathrm{CHT}$ or altering the fractionation, improves survival outcomes in locally advanced HNSCC. However, there are no direct comparative studies to propose definitive conclusions. Therefore, how do these literature data fit in routine clinical practice? SIB-IMRT is largely used but actually no high-quality evidence is available on its safety and efficacy compared to recommended standard cisplatin-based CRT using conventional fractionation. SIB-IMRT is mainly dictated by logistic issues, such as machine slots and patient 
convenience. The BED of SIB-IMRT is slightly higher than that of conventional fractions, but at present the optimal dose prescription is doubtful.

However, it remains i) to established whether AF jeopardizes treatment compliance and negatively affects toxicity profile and quality of life; ii) to evaluate radiobiological comparison between fractionation schemes in IMRT era; iii) to clarify whether HPV-positive and HPVnegative disease, despite their different radiosensitivity [46], benefit from the same SIB fractionation; iv) to test whether different systemic agents can be associated with AF RT to confer additional survival benefit minimizing morbidity. Hopefully, future clinical trials will be designed to vigorously pursue definitive recommendations.

\section{References}

1. National Comprehensive Cancer Network (NCCN). Guidelines Head and Neck Cancers, Version 3.2019. available at http://www.nccn.org

2. Mahal BA, Catalano PJ, Haddad RI, et al. Incidence and Demographic Burden of HPVAssociated Oropharyngeal Head and Neck Cancers in the United States. Cancer Epidemiol Biomarkers Prev. 2019;28:1660-1667.

3. Jiang L, Zhang Y, Yang Z, Liang F, Wu J, Wang R. A comparison of clinical outcomes between simultaneous integrated boost (SIB) versus sequential boost (SEQ) intensity modulated radiation therapy (IMRT) for head and neck cancer: A meta-analysis. Medicine (Baltimore). 2019;98:e16942. doi: 10.1097/MD.0000000000016942.

4. Bourhis J, Overgaard J, Audry H, et al. Meta-Analysis of Radiotherapy in Carcinomas of Head and neck (MARCH) Collaborative Group. Hyperfractionated or accelerated radiotherapy in head and neck cancer: a meta-analysis. Lancet. 2006;368:843-54. 
5. Lacas B, Bourhis J, Overgaard J, et al. Role of radiotherapy fractionation in head and neck cancers (MARCH): an updated meta-analysis. Lancet Oncol. 2017;18:1221-1237. doi: $10.1016 / S 1470-2045(17) 30458-8$

6. Nguyen LN, Ang KK. Radiotherapy for cancer of the head and neck: altered fractionation regimens. Lancet Oncol. 2002;3:693-701.

7. Beitler JJ, Zhang Q, Fu KK, et al. Final results of local-regional control and late toxicity of RTOG 9003: a randomized trial of altered fractionation radiation for locally advanced head and neck cancer. Int J Radiat Oncol Biol Phys. 2014;89:13-20. doi: 10.1016/j.ijrobp.2013.12.027

8. Nguyen-Tan PF, Zhang Q, Ang KK, et al. Randomized phase III trial to test accelerated versus standard fractionation in combination with concurrent cisplatin for head and neck carcinomas in the Radiation Therapy Oncology Group 0129 trial: long-term report of efficacy and toxicity. J Clin Oncol. 2014;32:3858-66. doi: 10.1200/JCO.2014.55.3925

9. Ang KK, Zhang Q, Rosenthal DI, et al. Randomized phase III trial of concurrent accelerated radiation plus cisplatin with or without cetuximab for stage III to IV head and neck carcinoma: RTOG 0522. J Clin Oncol. 2014;32:2940-50.

10. Overgaard J, Hansen HS, Specht L, et al. Five compared with six fractions per week of conventional radiotherapy of squamous-cell carcinoma of head and neck: DAHANCA 6 and 7 randomised controlled trial. Lancet. 2003;362:933-40.

11. Overgaard J, Mohanti BK, Begum N, et al. Five versus six fractions of radiotherapy per week for squamous-cell carcinoma of the head and neck (IAEA-ACC study): a randomised, multicentre trial. Lancet Oncol. 2010;11:553-60. doi: 10.1016/S14702045(10)70072-3

12. Gillison ML, Trotti AM, Harris J, et al. Radiotherapy plus cetuximab or cisplatin in human papillomavirus-positive oropharyngeal cancer (NRG Oncology RTOG 1016): a 
randomised, multicentre, non-inferiority trial. Lancet. 2019;393:40-50. doi: 10.1016/S0140-6736(18)32779-X

13. Lassen P, Lacas B, Pignon JP, et al. Prognostic impact of HPV-associated p16expression and smoking status on outcomes following radiotherapy for oropharyngeal cancer: The MARCH-HPV project. Radiother Oncol. 2018;126:107-115. doi: 10.1016/j.radonc.2017.10.018.

14. Mohan R, Wu Q, Manning M, Schmidt-Ullrich R. Radiobiological considerations in the design of fractionation strategies for intensity-modulated radiation therapy of head and neck cancers. Int J Radiat Oncol Biol Phys. 2000;46:619-30.

15. Joiner MC. Hyperfractionation and accelerated radiotherapy. In: Steel GG, editor. Basic clinical radiobiology. London: Arnold; 1997;123-31.

16. Thames HD Jr, Withers HR, Peters LJ, Fletcher GH. Changes in early and late radiation responses with altered dose fractionation: implications for dose-survival relationships. Int J Radiat Oncol Biol Phys. 1982;8:219-26.

17. Orlandi E, Palazzi M, Pignoli E, Fallai C, Giostra A, Olmi P. Radiobiological basis and clinical results of the simultaneous integrated boost (SIB) in intensity modulated radiotherapy (IMRT) for head and neck cancer: A review. Crit Rev Oncol Hematol. 2010;73:111-25. doi: 10.1016/j.critrevonc.2009.03.003.

18. Ho KF, Fowler JF, Sykes AJ, Yap BK, Lee LW, Slevin NJ. IMRT dose fractionation for head and neck cancer: variation in current approaches will make standardisation difficult. Acta Oncol. 2009;48:431-9. doi: 10.1080/02841860802372272.

19. Spiotto MT, Weichselbaum RR. Comparison of 3D conformal radiotherapy and intensity modulated radiotherapy with or without simultaneous integrated boost during concurrent chemoradiation for locally advanced head and neck cancers. PLoS One. 2014;9:e94456. doi: 10.1371/journal.pone.0094456. 
20. Vlacich G, Stavas MJ, Pendyala P, Chen SC, Shyr Y, Cmelak AJ. A comparative analysis between sequential boost and integrated boost intensitymodulated radiation therapy with concurrent chemotherapy for locallyadvanced head and neck cancer. Radiat Oncol 2017;12:13. doi: 10.1186/s13014-0160756-х.

21. Kuo YH, Liang JA, Wang TC, Juan CJ, Li CC, Chien CR. Comparative effectiveness of simultaneous integrated boost vs sequential intensity-modulated radiotherapy for oropharyngeal or hypopharyngeal cancer patients: A population-based propensity scorematched analysis. Medicine (Baltimore) 2019;98:e18474. doi: 10.1097/MD.0000000000018474.

22. Studer G, Peponi E, Kloeck S, Dossenbach T, Huber G, Glanzmann C. Surviving hypopharynx-larynx carcinoma in the era of IMRT. Int $\mathrm{J}$ Radiat Oncol Biol Phys 2010;77(5):1391-6. doi: 10.1016/j.jirobp.2009.07.005

23. Clavel S, Nguyen DH, Fortin B, et al. Simultaneous integrated boost using intensitymodulated radiotherapy compared with conventional radiotherapy in patients treated with concurrent carboplatin and 5-fluorouracil for locally advanced oropharyngeal carcinoma. Int J Radiat Oncol Biol Phys 2012;82:582-9. doi: 10.1016/j.jijrobp.2010.10.061

24. Daly ME, Le QT, Maxim PG, et al. Intensity-modulated radiotherapy in the treatment of oropharyngeal cancer: clinical outcomes and patterns of failure. Int J Radiat Oncol Biol Phys 2010;76:1339-46. doi: 10.1016/j.ijrobp.2009.04.006

25. Hassan Metwally MA, Ali R, Kuddu M, et al. IAEA-HypoX. A randomized multicenter study of the hypoxic radiosensitizer nimorazole concomitant with accelerated radiotherapy in head and neck squamous cell carcinoma. Radiother Oncol 2015;116:15-20. doi: 10.1016/j.radonc.2015.04.005. 
26. Mehanna H, Wong WL, McConkey CC, et al. PET-CT Surveillance versus Neck Dissection in Advanced Head and Neck Cancer. N Engl J Med 2016; 374:1444-54. doi: 10.1056/NEJMoa1514493

27. Tao Y, Auperin A, Sire C, et al. Improved Outcome by Adding Concurrent Chemotherapy to Cetuximab and Radiotherapy for Locally Advanced Head and Neck Carcinomas: Results of the GORTEC 2007-01 Phase III Randomized Trial. J Clin Oncol 2018; 7:JCO2017762518. doi: 10.1200/JCO.2017.76.2518.

28. Nutting CM, Morden JP, Harrington KJ, et al. Parotid-sparing intensity modulated versus conventional radiotherapy in head and neck cancer (PARSPORT): a phase 3 multicentre randomised controlled trial. Lancet Oncol. 2011;12:127-36.

29. Mehanna H, Robinson M, Hartley A, et al. Radiotherapy plus cisplatin or cetuximab in low-risk human papillomavirus-positive oropharyngeal cancer (De-ESCALaTE HPV): an open-label randomised controlled phase 3 trial. Lancet 2019; 393:51-60. doi: $10.1016 / S 0140-6736(18) 32752-1$

30. Lauve A, Morris M, Schmidt-Ullrich R, et al. Simultaneous integrated boost intensitymodulated radiotherapy for locally advanced head-and-neck squamous cell carcinomas: II--clinical results. Int J Radiat Oncol Biol Phys. 2004;60:374-87.

31. Leclerc M, Maingon $P$, Hamoir M, et al. A dose escalation study with intensity modulated radiation therapy (IMRT) in T2N0, T2N1, T3N0 squamous cell carcinomas (SCC) of the oropharynx, larynx and hypopharynx using a simultaneous integrated boost (SIB) approach. Radiother Oncol. 2013;106:333-40.

32. Bhide SA, Gulliford S, Fowler J, et al. Characteristics of response of oral and pharyngeal mucosa in patients receiving chemo-IMRT for head and neck cancer using hypofractionated accelerated radiotherapy. Radiother Oncol. 2010;97:86-91. 
33. Gujral DM, Miah AB, Bodla $S$, et al. Final long-term results of a phase I/II study of doseescalated intensity-modulated radiotherapy for locally advanced laryngohypopharyngeal cancers. Oral Oncol. 2014;50:1089-97.

34. Thomson DJ, Ho KF, Ashcroft L, et al. Dose intensified hypofractionated intensitymodulated radiotherapy with synchronous cetuximab for intermediate stage head and neck squamous cell carcinoma. Acta Oncol. 2015;54:88-98.

35. Pignon JP, le Maître A, Maillard E, Bourhis J; MACH-NC Collaborative Group. Metaanalysis of chemotherapy in head and neck cancer (MACH-NC): an update on 93 randomised trials and 17,346 patients. Radiother Oncol. 2009;92:4-14.

36. Gupta T, Kannan S, Ghosh-Laskar S, Agarwal JP. Systematic Review and Meta-analysis of Conventionally Fractionated Concurrent Chemoradiotherapy versus Altered Fractionation Radiotherapy Alone in the Definitive Management of Locoregionally Advanced Head and Neck Squamous Cell Carcinoma. Clin Oncol (R Coll Radiol). $2016 ; 28: 50-61$

37. Fallai C, Bolner A, Signor M, et al. Long-term results of conventional radiotherapy versus accelerated hyperfractionated radiotherapy versus concomitant radiotherapy and chemotherapy in locoregionally advanced carcinoma of the oropharynx. Tumori 2006;92:41-54.

38. Bourhis J, Sire C, Graff P, et al. Concomitant chemoradiotherapy versus acceleration of radiotherapy with or without concomitant chemotherapy in locally advanced head and neck carcinoma (GORTEC 99-02): an open-label phase 3 randomised trial. Lancet Oncol 2012;13:145-153.

39. Ghosh-Laskar S, Kalyani N, Gupta T, et al. Conventional radiotherapy versus concurrent chemoradiotherapy versus accelerated radiotherapy in locoregionally advanced carcinoma of head and neck: Results of a prospective randomized trial. Head Neck 2016;38:202-7. 
40. Chitapanarux I, Tharavichitkul E, Kamnerdsupaphon P, Pukanhapan N, Vongtama R. Randomized phase III trial of concurrent chemoradiotherapy vs accelerated hyperfractionation radiotherapy in locally advanced head and neck cancer. J Radiat Res 2013;54:1110-1117.

41. Rishi A, Ghoshal S, Verma R, et al. Comparison of concomitant boost radiotherapy against concurrent chemoradiation in locally advanced oropharyngeal cancers: a phase III randomised trial. Radiother Oncol 2013;107:317-24.

42. Haussmann J, Tamaskovics B, Bölke E, et al. Addition of chemotherapy to hyperfractionated radiotherapy in advanced head and neck cancer-a meta-analysis. Strahlenther Onkol 2019; 195:1041-1049. doi: 10.1007/s00066-019-01511-z

43. Blanchard P, Hill C, Guihenneuc-Jouyaux C, Baey C, Bourhis J, Pignon JP; MACH-NC and MARCH Collaborative Groups. Mixed treatment comparison meta-analysis of altered fractionated radiotherapy and chemotherapy in head and neck cancer. J Clin Epidemiol. 2011;64:985-92.

44. Strojan P, Vermorken JB, Beitler JJ, et al. Cumulative cisplatin dose in concurrent chemoradiotherapy for head and neck cancer: A systematic review. Head Neck. 2016;38 Suppl 1:E2151-8.

45. Spreafico A, Huang $\mathrm{SH}, \mathrm{Xu} \mathrm{W}$, et al. Impact of cisplatin dose intensity on human papillomavirus-related and -unrelated locally advanced head and neck squamous cell carcinoma. Eur J Cancer. 2016;67:174-182.

46. Marcu LG. Future treatment directions for HPV-associated head and neck cancer based on radiobiological rationale and current clinical evidence. Crit Rev Oncol Hematol. 2016;103:27-36. 


\section{Captions and legends}

\section{table 1: SIB-IMRT main retrospective series.}

IMRT: intensity modulated radiotherapy; 2D: two dimensional; 3D: three- dimensional; RT: radiotherapy; SEQ: sequential; SIB; Simultaneous integrated boost; BID: bifractionation; fr: fraction; OTT: overall treatment time; FU: follow-up; Gy: Gray; PFS: progression-free survival; y: year; vs: versus; LC: local control; RC: regional control; LRC: locoregional control; CRT: conventional chemoradiotherapy; HPV: human papilloma virus; LC: local control; DFS: disease-free survival; OS: overall survival; mo: months; y: years, NA: not available vailable; $\mathrm{CHT}$ :chemotherapy

\section{table 2: randomized phase 3 trials.}

IMRT: intensity modulated radiotherapy; fr: fraction; OTT: overall treatment time; FU: followup; RCT: randomized clinical trial; CHT:chemotherapy; cetux: cetuximab; RT: radiotherapy; Gy: Gray; PFS: progression-free survival; y: year; vs: versus; LRC: loco-regional control; HPV: human papilloma virus; NIM: nimorazole; SIB: simultaneous integrated boost; LRF: loco-regional failure; OS: overall survival; 2D: two dimensional; 3D: three dimensional; G: grade ; AUC: area under the curve; NA: not available 
Table 1

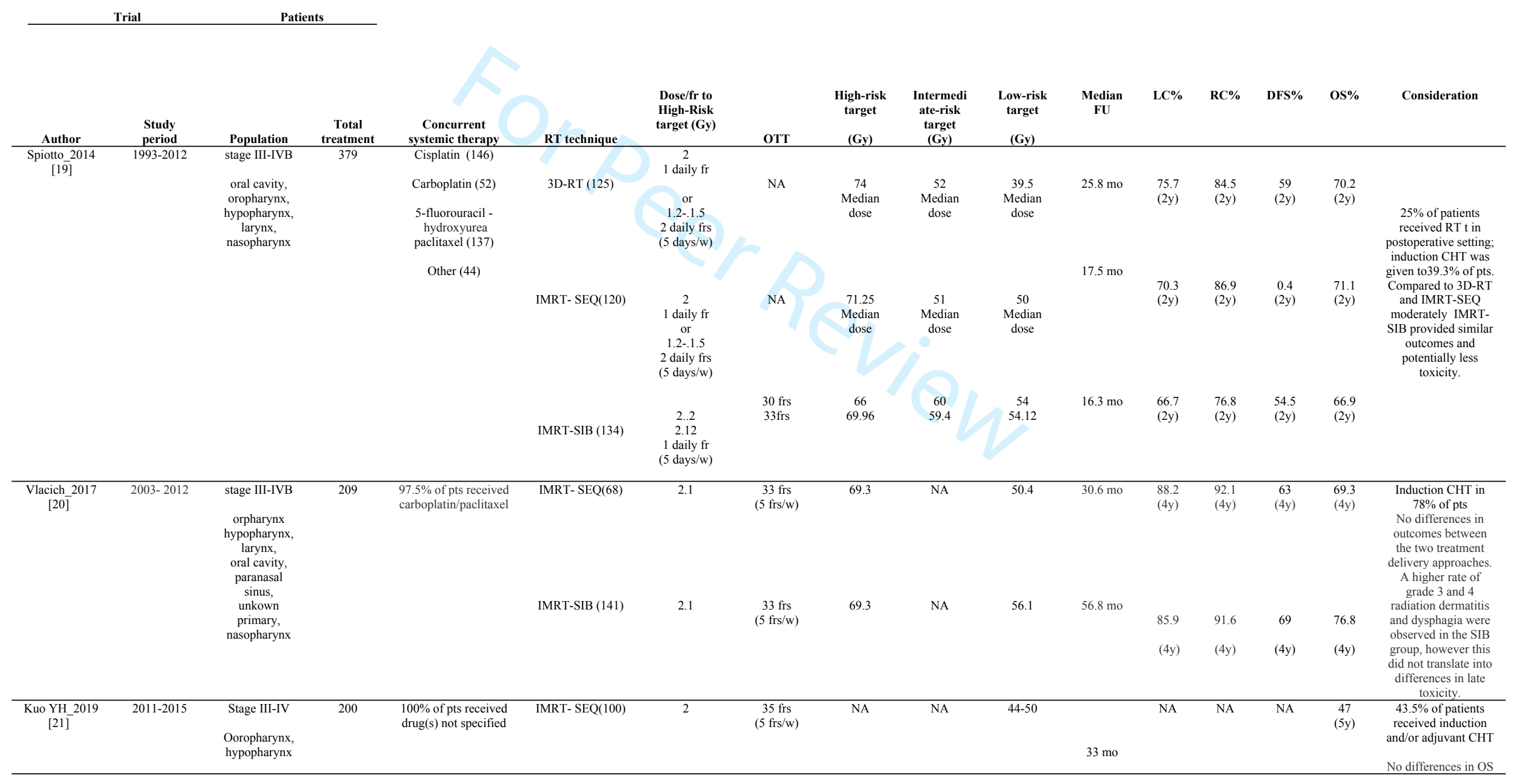




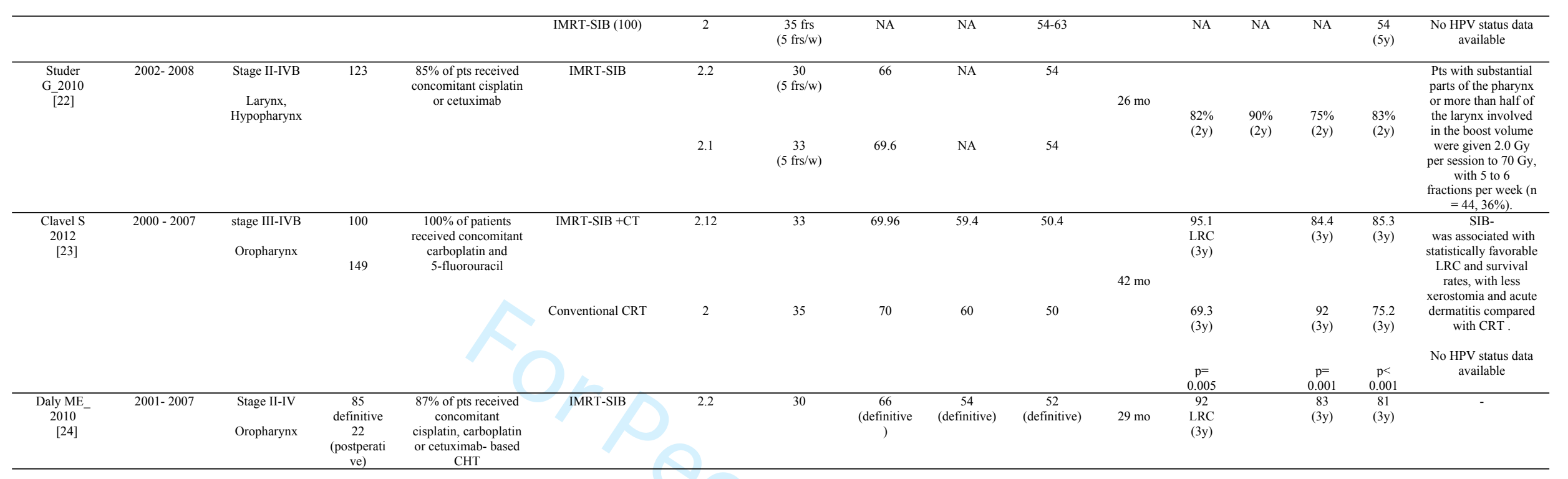


Table 2.

\begin{tabular}{|c|c|c|c|c|c|c|c|c|c|c|c|c|c|c|c|c|c|c|c|}
\hline \multirow{3}{*}{$\begin{array}{l}\text { Author } \\
\text { Ang_2014 } \\
{[9]}\end{array}$} & \multicolumn{3}{|c|}{ Trial } & \multicolumn{2}{|l|}{ Patients } & \multirow[b]{2}{*}{ Treatment } & \multirow[b]{2}{*}{ Concurrent systemic therapy } & \multirow[b]{2}{*}{ IMRT } & \multirow[b]{2}{*}{ Technique } & \multirow[b]{2}{*}{$\begin{array}{l}\text { Total } \\
\text { dose }\end{array}$} & \multirow[b]{2}{*}{$\begin{array}{c}\text { Dose } \\
\text { fr }\end{array}$} & \multirow[b]{2}{*}{ отT } & \multirow[b]{2}{*}{$\begin{array}{c}\text { Definitive } \\
\text { planning } \\
\text { dose }\end{array}$} & \multirow{2}{*}{$\begin{array}{c}\begin{array}{c}\text { High- } \\
\text { risk } \\
\text { target }\end{array} \\
\mathrm{NA}\end{array}$} & \multirow[b]{2}{*}{$\begin{array}{c}\begin{array}{c}\text { Low- } \\
\text { risk } \\
\text { target }\end{array} \\
\mathrm{NA}\end{array}$} & \multirow[b]{2}{*}{$\begin{array}{c}\text { Median } \\
\text { FU }\end{array}$} & \multirow{2}{*}{$\begin{array}{c}\begin{array}{c}\text { Primary } \\
\text { end point }\end{array} \\
\text { PFS }\end{array}$} & \multirow[b]{2}{*}{$\begin{array}{c}\text { Outcomes } \\
\end{array}$} & \multirow[b]{2}{*}{ Consideration } \\
\hline & Acronym & Type & $\begin{array}{c}\text { Enrollment } \\
\text { time }\end{array}$ & Population & Total & & & & & & & & & & & & & & \\
\hline & RTOG 0522 & $\begin{array}{c}\text { Phase } \\
\text { III } \\
\text { RCT }\end{array}$ & $\begin{array}{l}\text { Nov } 2005- \\
\text { May } 2009\end{array}$ & $\begin{array}{l}\text { stage III-IV } \\
\text { oropharynx, } \\
\text { hypopharynx, } \\
\text { larynx }\end{array}$ & 891 & $\begin{array}{c}\text { CHT-RT } \\
\text { (447) vs } \\
\text { CHT- } \\
\text { cetux-RT } \\
(444) \\
\end{array}$ & $\begin{array}{l}\text { Cisplatin } 100 \mathrm{mg} / \mathrm{m} 2 \text { (on days } 1 \text { and } \\
22)+/ \text { weekly cetux } 250 \mathrm{mg} / \mathrm{m} 2 \\
(400 \mathrm{mg} / \mathrm{m} 2 \text {, loading dose })\end{array}$ & 771 & $\mathrm{NA}$ & $\begin{array}{l}70 \\
\text { Gy }\end{array}$ & 2 Gy & $\begin{array}{c}6 \\
\text { weeks }\end{array}$ & $\mathrm{NA}$ & $\mathrm{NA}$ & & $\begin{array}{c}3.8 \\
\text { years }\end{array}$ & PFS & $\begin{array}{c}\text { Similar 3-y PFS (61.2\% vs 58.9\%), } \\
\text { 3-y OS (72.9\% vs 75.8\%), } \\
\text { 3-y LRF (19.9\% vs } 25.9 \%) \\
\text { 3-y DM (13\% vs 9,7\%) }\end{array}$ & $\begin{array}{l}419(93.7 \%) \text { and } 402 \\
(90.5 \%) \text { patients } \\
\text { received } 2 \text { cycles of } \\
\text { cisplatin }\end{array}$ \\
\hline $\begin{array}{l}\text { Gillison_2018 } \\
{[12]}\end{array}$ & RTOG 1016 & $\begin{array}{c}\text { Phase } \\
\text { III } \\
\text { RCT }\end{array}$ & $\begin{array}{l}\text { Jun 2011- } \\
\text { Jul } 2014\end{array}$ & $\begin{array}{l}\text { HPVpositive } \\
\text { oropharyngeal } \\
\text { carcinoma (T1-2 } \\
\text { N2a-3 or T3-4 } \\
\text { No-3) }\end{array}$ & 849 & $\begin{array}{l}\text { cetux-RT } \\
\text { (425) vs } \\
\text { CHT-RT } \\
(424)\end{array}$ & $\begin{array}{l}\text { cetux } 250 \mathrm{mg} / \mathrm{m} 2(400 \mathrm{mg} / \mathrm{m} 2, \\
\text { loading dose) or Cisplatin } 100 \\
\mathrm{mg} / \mathrm{m} 2 \text { (on days } 1 \text { and } 22)\end{array}$ & 849 & NA & $\begin{array}{l}70 \\
\text { Gy }\end{array}$ & 2 Gy & $\begin{array}{c}6 \\
\text { weeks }\end{array}$ & NA & NA & $\mathrm{NA}$ & $\begin{array}{l}4.5 \\
\text { years }\end{array}$ & OS & 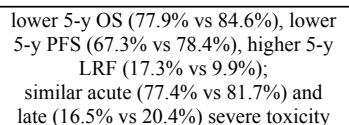 & $\begin{array}{l}377(93 \%) \text { patients } \\
\text { received } 2 \text { cycles of } \\
\text { cisplatin }\end{array}$ \\
\hline $\begin{array}{l}\text { Metwally_2015 } \\
\text { [25] }\end{array}$ & $\begin{array}{l}\text { IAEA- } \\
\text { HypoX }\end{array}$ & $\begin{array}{l}\text { Phase } \\
\text { III } \\
\text { RCT }\end{array}$ & $\begin{array}{l}\text { Mar 2012- } \\
\text { May 2014 }\end{array}$ & $\begin{array}{l}\text { stage I-IV oral } \\
\text { cavity, } \\
\text { oropharynx, } \\
\text { hypopharynx, } \\
\text { larynx (except } \\
\text { I-II larynx) }\end{array}$ & 82 & $\begin{array}{l}\text { NIM-RT } \\
\text { (39) vs } \\
\text { RT (43) }\end{array}$ & NIM H61.2 $\mathrm{g} / \mathrm{m} 2$ body surface area & $\begin{array}{l}25(12 \\
+13)\end{array}$ & $\begin{array}{c}\mathrm{SIB} \\
\mathrm{S}\end{array}$ & $\begin{array}{l}66- \\
70 \\
\text { Gy }\end{array}$ & 2 Gy & $\begin{array}{c}6 \\
\text { weeks }\end{array}$ & $\begin{array}{l}66-70 \mathrm{~Gy} \\
(2 \mathrm{~Gy} / \mathrm{fr})\end{array}$ & $\begin{array}{c}60 \text { Gy } \\
(1.7- \\
1.8 \\
\text { Gy/fr) }\end{array}$ & $\begin{array}{l}50 \\
(1.4- \\
1.5 \\
\text { Gy/fr) }\end{array}$ & $\begin{array}{c}19 \\
\text { months }\end{array}$ & LRF & $\begin{array}{c}\text { Similar 2-y LRF (55\% vs 56\%) and } \\
2 \text {-y OS (51\% vs } 29 \%)\end{array}$ & $\begin{array}{c}\text { Most patients }(\mathrm{n}=56) \\
\text { received 2D RT }\end{array}$ \\
\hline $\begin{array}{l}\text { Mehanna_2016 } \\
{[26]}\end{array}$ & $\begin{array}{l}\text { PET-NECK } \\
\end{array}$ & $\begin{array}{c}\text { Phase } \\
\text { III } \\
\text { RCT }\end{array}$ & $\begin{array}{l}\text { Oct 2007- } \\
\text { Aug 2012 }\end{array}$ & $\begin{array}{l}\text { stage N2-3 nodal } \\
\text { oropharynx, } \\
\text { hypopharynx, } \\
\text { larynx, oral } \\
\text { cavity, occult } \\
\end{array}$ & 564 & CHT-RT & $\begin{array}{l}\text { at least two doses of concomitant } \\
\text { three/four weekly cisplatin } 75- \\
100 \mathrm{mg} / \mathrm{m} 2 \text { or carboplatin } 4.5-5 \text { AUC } \\
\text { or weekly cetux } 250 \mathrm{mg} / \mathrm{m} 2 \\
(400 \mathrm{mg} / \mathrm{m} 2, \text { loading dose }) \\
\end{array}$ & 332 & $\begin{array}{l}\text { SIB; } \\
\text { sequential }\end{array}$ & $\begin{array}{l}65 \\
\text { Gy; } \\
70 \\
\text { Gy }\end{array}$ & $\begin{array}{l}2.16 \\
\text { Gy; } \\
2 \text { Gy }\end{array}$ & $\begin{array}{c}6 \\
\text { weeks; } \\
7 \\
\text { weeks }\end{array}$ & $\mathrm{NA}$ & NA & $\mathrm{NA}$ & $\begin{array}{c}36 \\
\text { months }\end{array}$ & OS & $2-y$ OS $83.2 \%$ & \\
\hline $\begin{array}{l}\text { Tao_2018 } \\
{[27]}\end{array}$ & $\begin{array}{l}\text { GORTEC } \\
2007-01\end{array}$ & $\begin{array}{l}\text { Phase } \\
\text { III } \\
\text { RCT }\end{array}$ & $\begin{array}{l}\text { Jan } 2008- \\
\text { Mar } 2014\end{array}$ & $\begin{array}{l}\text { stage III-IV (N0- } \\
\text { 2b) oral cavity, } \\
\text { oropharynx, } \\
\text { hypopharynx, } \\
\text { larynx } \\
\end{array}$ & 406 & $\begin{array}{c}\text { CHT- } \\
\text { cetux-RT } \\
\text { (204) } \\
\text { vs cetux- } \\
\text { RT (202) } \\
\end{array}$ & $\begin{array}{l}\text { weekly cetux } 250 \mathrm{mg} / \mathrm{m} 2 \text { ( } 400 \\
\mathrm{mg} / \mathrm{m} 2, \text { loading dose })+/-3 \text { cycles of } \\
\text { carboplatin } 70 \mathrm{mg} / \mathrm{m} 2 \text { on days } 1 \text { to } 4 \\
\text { and } \mathrm{FU} 600 \mathrm{mg} / \mathrm{m} 2 \text { on days } 1 \text { to } 4\end{array}$ & $\begin{array}{c}164 \\
(80+ \\
84)\end{array}$ & $\begin{array}{l}\text { Sequential } \\
\text { S }\end{array}$ & $\begin{array}{l}70 \\
\text { Gy }\end{array}$ & $2 \mathrm{~Gy}$ & $\begin{array}{c}7 \\
\text { weeks }\end{array}$ & $\begin{array}{l}70 \mathrm{~Gy} \\
(2 \mathrm{~Gy} / \mathrm{fr})\end{array}$ & & $\begin{array}{l}50 \text { Gy } \\
(2 \\
\text { Gy/fr) }\end{array}$ & $\begin{array}{l}4.4 \\
\text { years }\end{array}$ & PFS & $\begin{array}{l}\text { CHT-cetux-RT higher 3-y PFS ( } 52.3 \% \\
\text { vs } 40.5 \%) \text {, lower LCF (21.6\% vs } \\
38.8 \% \text { ), higher severe mucosistis }(73 \% \\
\text { vs } 61 \%) \text { and hospitalizations }(42 \% \text { vs } \\
22 \% \text { ) } \\
\end{array}$ & \\
\hline $\begin{array}{l}\text { Mehanna_2018 } \\
\text { [29] }\end{array}$ & $\begin{array}{l}\text { De- } \\
\text { ESCALaTE } \\
\text { HPV }\end{array}$ & $\begin{array}{l}\text { Phase } \\
\text { III } \\
\text { RCT }\end{array}$ & $\begin{array}{l}\text { Nov } 2012- \\
\text { Oct } 2016\end{array}$ & $\begin{array}{c}\text { HPV-positive } \\
\text { low-risk } \\
\text { oropharyngeal } \\
\text { cancer (T3-4N0, } \\
\text { and T1N1-T4N3) }\end{array}$ & 334 & $\begin{array}{l}\text { CHT-RT } \\
\text { (166) vs } \\
\text { cetur-RT } \\
(168)\end{array}$ & $\begin{array}{l}\text { cisplatin } 100 \mathrm{mg} / \mathrm{m} 2 \text { (on days } 1,22, \\
\text { and } 433 \text { or weekly cetux } 250 \mathrm{mg} / \mathrm{m} 2 \\
(400 \mathrm{mg} / \mathrm{m} 2 \text {, loading dose })\end{array}$ & 332 & $\begin{array}{l}\text { Sequential } \\
\text { Sel }\end{array}$ & $\begin{array}{l}70 \\
\text { Gy }\end{array}$ & 2 Gy & $\begin{array}{c}7 \\
\text { weeks }\end{array}$ & $\mathrm{NA}$ & NA & $\mathrm{NA}$ & $\begin{array}{l}25.9 \\
\text { months }\end{array}$ & $\begin{array}{l}\text { overall } \\
\text { acute and } \\
\text { late severe } \\
\text { toxicity }\end{array}$ & $\begin{array}{c}\text { Similar severe toxicity, } \\
\text { higher 2-y OS (97.5\% vs 89.4\%) } \\
\text { and lower 2-y LRC (6\% vs } 16.1 \%)\end{array}$ & $\begin{array}{c}62(38 \%) \text { patients } \\
\text { received } 3 \text { cycles of } \\
\text { cisplatin, } 83(51 \%) \\
\text { received } 2 \text { cycles, and } \\
16(10 \%) \text { received } 1 \\
\text { cycle }\end{array}$ \\
\hline
\end{tabular}

